European Journal of Medical and Health Sciences, 3(6), 136-146, 2021

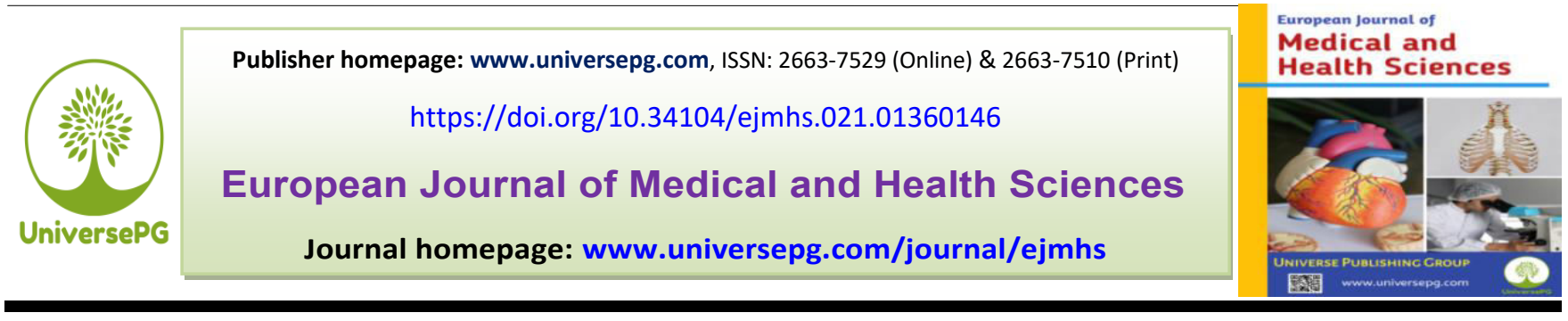

\title{
Isolation and Identification of Pathogenic Bacteria from Baime Fish (Mystus armatus) and Evaluation of Antibiotic Susceptibility
}

\author{
Rintu Kumar Sarker ${ }^{1}$, Md. Khasrul Alam ${ }^{1}$, Md. Anwar Hossain ${ }^{2}$, Md. Badiruzzaman ${ }^{3}$, Abdul Hamid , \\ Md. Abdullah Al Rabbni ${ }^{4}$, and Md. Rezuanul Islam ${ }^{1}$ \\ ${ }^{1}$ Dept. of Biotechnology and Genetic Engineering, Islamic University, Bangladesh; ${ }^{2}$ Dept. of Biotechnology and Genetic \\ Engineering, Noakhali Science and Technology University, Bangladesh; ${ }^{3}$ Dept. of Biochemistry and Molecular Biology, \\ University of Dhaka, Bangladesh; and ${ }^{4}$ Dept. of Biochemistry and Molecular Biology, Gono Bishwabidyalay, Bangladesh. \\ *Correspondence: manik.bge@gmail.com (Dr. Md. Khasrul Alam, Associate Professor, Dept. of Biotechnology and Genetic \\ Engineering, Islamic University, Bangladesh).
}

\section{ABSTRACT}

Aquaculture products (fish) can harbor pathogenic bacteria which are part of the natural micro-flora of the environment. The current study was carried out for the extraction and identification of fish pathogenic microbes from Baime fish (Mystus armatus). Diseased fresh-water fishes were collected from different water bodies and fish landing centers of two study areas, namely the City area, Jhenaidah region. Bacteria are one of the important causative agents of fish diseases in both wild and cultured fish and are responsible for serious economic losses. Pathogenic bacteria strain was isolated from the infected area of Baime (M. armatus) fish skin. After isolation, isolates were finally identified by their desire morphological, characteristics and biochemical test. They were gram-negative, rod-shaped bacteria that showed positive reaction for catalase, able to ferment glucose and one is citrate negative and another is citrate positive. After being persuaded above-mentioned test isolates were identified as genus Aeromonas and Pseudomonas. The ulcer type disease of M. armatus, the isolate was tested against several antibiotics' treatment. Pseudomonas strains isolated from M. armatus is susceptible to penicillin $\mathrm{G}(10 \mu \mathrm{g})$, amoxycillin $(10 \mu \mathrm{g})$, erythromycin $(15 \mu \mathrm{g})$, Tetracycline $(30 \mu \mathrm{g})$, Kanamycine $(30 \mu \mathrm{g})$, moderately susceptible to Co-trimoxazole $(25 \mu \mathrm{g})$, and Resistance to ceftazidime $(10 \mu \mathrm{g})$. Aeromonas strains isolated from M. armatus is susceptible to amoxycillin $(10 \mu \mathrm{g})$, erythromycin $(15 \mu \mathrm{g})$, Tetracycline $(30 \mu \mathrm{g})$, moderately susceptible to ceftazidime $(10 \mu \mathrm{g})$ and Resistance to Co-trimoxazole $(25 \mu \mathrm{g})$, penicillin $\mathrm{G}(10 \mu \mathrm{g})$, Kanamycine $(30 \mu \mathrm{g})$. The results of the present study constitute an advance in the available diagnostic and bacterial pathogens in fish farms.

Keywords: Isolation, Identification, Pathogenic bacteria, Mystus armatus, evaluation, and antibiotic susceptibility.

\section{INTRODUCTION:}

Fish is a vital source of food for people and contributes about $60 \%$ of the world's supply of protein. It is a high quality food item. Fish muscle contains almost all the essential nutrients required for human health. Quantity wise, water is the major constituent of fish which varies between $60-90 \%$. Also fish contains proteins (15-24\%), UniversePG I www.universepg.com lipids (0.2-65\%), ash (0.4-2\%), vitamins (both fat and water soluble), and considerable amount of carbohydrates, and non-protein nitrogenous compounds (free amino acids, nucleotides, peptides, etc.). Fish is considered as one of the most delicious and an essential food over the world. First consideration is the sources of protein. Major portion of protein comes from animal 
sources and a small amount is coming from plant sources. Among the animal protein sources, fish is still considered as the cheapest sources of animal protein. $60 \%$ of the developing countries derive $30 \%$ of their annual protein from fish (Abisoye et al., 2011). Though price some species of fish is much higher but there are many fishes in the markets whose price is in the limit of buying capability of general people of the country. Bangladesh is furnished with diversified natural fisheries resources. Different types of water bodies both fresh water and marine are present in this country. There are 260 native and at least 12 exotic species (Rahman, 2005) of fishes are now available in Bangladesh. There was a time when natural water bodies of the country were full of fishes and other fisheries items. But situation has changed now and our open water losing their resources and production from cultural water bodies increased to a great extent but still beyond the level of country requirement.

Bangladesh is one of the world's leading fish producing countries. In year 1994-95, total fisheries production of Bangladesh was 1,172,868 metric tons including 908, 218 metric tons from inland $(317,073$ metric tons culture and 591,145 metric tons capture) and 264,650 metric tons from marine sources. In year 2000-01 total production was $1,781,057$ metric tons inland capture 688,920 metric tons ,inland culture 712,640 metric tons and 379,497 metric tons from marine sources). In the year 2005-06, total production of fisheries was reached to 2328545 metric tons including 1848735 metric tons inland (capture 956686 metric tons and culture 892049 metric tons) and 479810 metric tons marine production (Abedin et al., 2021; Balachandran, 2001).

Mystus armatus is a fish in genus Mystus. It is a native fish to Bangladesh. It is popular for its taste. It lives in ponds, rivers, canals etc. Its maximum length is $20-28$ centimeters (6.2 in). It eats protozoa, algae, etc. It is a slow-moving fish, so with any dynamic and aggressive it will be nervous. The age and growth of $M$. armatus studied by the evaluation of annuli found on the range and by length-frequency distribution. The fish attained lengths of 119, 194, 286, 298, 325, 375 and $453 \mathrm{~mm}$ at the end of the $1^{\text {st }}, 2^{\text {nd }}, 3^{\text {rd }}, 4^{\text {th }}, 5^{\text {th }}, 6^{\text {th }}$, and $7^{\text {th }}$ years of life respectively. The increase in length of scale bears a constant relationship with the increase in length of fish. The growth ratio of the fish was found higher during UniversePG I www.universepg.com the $1^{\text {st }}$ and $2^{\text {nd }}$ years and gradually diminished afterwards till the $7^{\text {th }}$ year. Both sexes showed more or less similar growth ratio. The seasonal growth curve was chiefly govern by feeding intensity in fishes of 1st year class; while in adults it was infected by feeding intensity as well as/by maturation of the gonads. The body is elongated. Its dorsal profile is more convex than the ventral. The snout slightly projects beyond the mouth, often studded with pores. A pair of small maxillary barbells is hidden inside the labial fold. The dorsal derives midway between the snout tip and the anterior base of anal. Pelvics derive slightly nearer to the snout tip than to the caudal base. It is bluish or darkish on upper half, silvery below, and the opercle is glowing orange. Its food comprises crustaceans and an insect larva in early stages. This fish is found through-out India (Wig Bengal, Odisha, Tripura etc.) and Bangladesh. Ponds, rivers, rivulets are its main habitats.

\section{Literature review}

Bangladesh has bring off remarkable progress in the fisheries area since its independence in 1971 and this field have been playing a very significant role and deserve potential for future development in the agrarian economy of Bangladesh (DoF, 2015). The sector's contribution to the national economy is much higher than its $3.61 \%$ share in GDP, as it provides about $60 \%$ of the animal protein intake and more than $11 \%$ of the total population of the country is directly or indirectly involved in this sector for their livelihoods (DoF, 2015). Fish are aquatic vertebrate animals that are typical ectothermic (previously cold-blooded). They have a stream lined bodies that allow them to swim rapidly. They extract oxygen from water using gills or an accessory breathing organ to enable them to breathe atmospheric oxygen. Fish have two sets of paired fins, usually one or two (rarely three) dorsal fins, anal fin, and tail fin. Cultured fish suffer from Aeromonas sp. and Pseudomonas sp. infections with similar signs like dermal lesion, scale loss, frayed fins, tail and fin rot and dropsy. Ulcer type disease is caused by Pseudomonas fluorescens and Aeromonas hydrophila in Bangladesh.

There has been a steady increase in the numbers of bacterial species associated with fish diseases, with new pathogens regularly recognized in the scientific literature. According to (Austin and Austin,1999) potential bacterial pathogens that infect fishes are: Acineto- 
bacter spp., Aeromonas hydrophila, A. salmonicida, Citrobacter freundii Edward siellatarda, E. vulneris, Hafniaalvei, Klebsiella pneumoniae, Moraxella spp, Pantoea spp, Photobacterium damsela, Plesiomonas shigelloides, Providencia rettgeri, Pseudomonas aeruginosa, P. Fluorescens, P. putida, Salmonella arizonae, Serratia liquefaciens, Serratia plymuthica, Shewanella putrefaciens, Vibrio alginolyticus, $V$. cholera and $V$. vulnificus. Edwardsiella species are Gram-negative, rod-shaped bacteria. Edward siellatarda and E. ictaluri produced two different diseases (Noga, 1996). Bacterial gill disease (BGD) is caused by a variety of bacteria including Flexibacter columnaris, F. psychrophilia, Cytophaga psychrophila, and various species of Flavobacierium. Currently, a suggested name for this agent is Cytophaga columnaris, although it has also been called F. columnaris (Noga, 1996). According to Noga, (1996), motile aeromonad infection (MAI) is likely the most common bacterial disease of fresh waterfish, all of which are probably susceptible. Motile aeromonas can also inhabit brackish water but they decrease in prevalence with increasing salinity. MAI may be peracute, with few signs, or acute with hemorrhages associate with ulcerative lesions of the skin. In the chronic condition, there may be large, long-standing ulcers, and often associated with as cites (Fijan et al., 1971). Pathogenic Aeromonas sobria has been identified as causative agent of ulcerative fish disease in fanned European perch (Goldschmidt el al., 2008). Pseudomonas species are Gram-negative, rod-shaped, non spore forming bacteria, distributed widely in nature and found in soil and in water. Pseudomonas spp is commonly associated with fish eggs, skin, gills, and intestines. In Sudan Hnadi, (2008) reported the presence of Pseudomonas spp in gills and intestines of Oreochromis niloticus fishes. Mohammed, (1999) isolated Pseudomonas aeruginosa from apparently healthy $O$. nilotlcus fish and diseased fish. Tripathy et al. (2007) isolated $P$. aeruginosa from intestine of fresh water fish and from pond sediment. $P$. fluorescens is known to be part of the normal flora in the intestines of tilapia. $P$. Anguilliseptica was originally described as the bacterial causative agent of "Sekiten-byo" ulcer type disease of pond cultured Japanese eel. Berthe et al. (1995) and Domenech et al. (1997) isolated P. Anguilliseptica from eye, kidney, and spleen, liver and ascetic fluid of Baltic herring. P. aeruginosa and $P$. putida were reUniversePG I www.universepg.com ported from different parts of a number of fish species. Pseudomonas spp was isolated from intestine, skin and gills of number of fish species. However, secondary occurrence of pseudomonads was found to be rather occasional in several culture and wild fish species of Southeast Asia. Later on, even colonies of P. aeruginosa were detected on the surface and muscle lesions of several UDS afflicted fish species including the channids. In man $P$. aeruginosa causes between 10 $20 \%$ of infection in mosthospitals. Pseudomonas infection is especially prevalent among patient with burn wounds, cystic fibrosis and acute leukemia.The most serious infections caused by Pseudomonas include malignant external otitis, endopthalmitis, endocarditis, meningitis, pneumonia and sepnceamia.

\section{Aims and objectives of the study}

The aim of the present study was to screening the pathogenic bacterial strains from fish and established antibiotic treatment against them. However, to fulfill the aim the following objectives were persuaded in this study:

1) Isolation and identification of common fish pathogenic bacteria from infected fish $M$. armatus from pond water.

2) Biochemical confirmation of the isolates and comparison with reference strains.

3) To determine the potentiality of isolated bacteria against respective antibiotics.

\section{MATERIALS AND METHODS:}

Material - Infected Baime fish (Mystus armatus)

\section{Collection and processing of sample}

Specimens of M. armatus (Baime) were collected from pond water located around Jhenaidah, Bangladesh. Along with natural feeding, the fish were fed a mixture of fish meal, rice bran and different oil cakes as supplementary feed. The pond was free from sewage discharge and other anthropogenic activities. The ranges of water quality parameters during the collection period were: temperature $26.1-27.5^{\circ} \mathrm{C}, \mathrm{pH}$ 7.1-7.5. Two specimens were obtained from each collection pond, and thus altogether 4 fish (average live weight $120 \mathrm{gm}$ ) were collected, brought to the laboratory with oxygen packing. Prior to sacrifice, the fish were starved for 48 h. Ventral outsides were sterilized using $70 \%$ ethanol and baime fish were anatomized aseptically to remove 
the intestine. The GI tract was cleaved into proximal (PI) and distal (DI) parts and processed according to for extraction of autochthonous microorganisms. Gut segments from two specimens of $M$. armatus were pooled together region-wise for each replicate. Pooled samples of 2 fish were used for each replicate to avoid erroneous conclusions due to individual disparity in gut microbiota as described elsewhere.
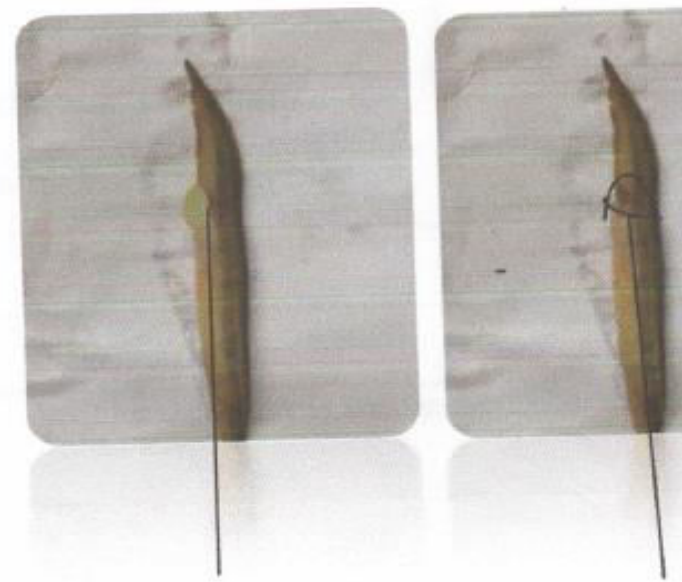

Fig 1: Fresh water non-infected Baime (Left) fish and Fresh water infected Baime (Right) fish.

\section{Media Used}

Tryptic soya agar (TSA) and Brain Heart Infusion Agar (BHIA) media was used for the isolation of pathogenic organisms from (M. armatus).

Table 1: Composition of Tryptic soya agar (TSA) media.

\begin{tabular}{|c|c|}
\hline Ingredients & Concentrations $(\mathrm{gm} / \mathrm{L})$ \\
\hline $\mathrm{Soy}$ & 5 \\
\hline $\mathrm{NaCl}$ & 5 \\
\hline Casein & 15 \\
\hline $\mathrm{Agar}$ & 15 \\
\hline $\mathrm{DDH}_{2} \mathrm{O}$ & $1 \mathrm{~L}$ \\
\hline
\end{tabular}

The desired $\mathrm{pH}$ of the media $7.3 \pm 2$

Table 2: Composition of Brain Heart Infusion Agar (BHIA) media.

\begin{tabular}{|c|c|}
\hline Ingredients & Concentrations $(\mathbf{g m} / \mathbf{L})$ \\
\hline Brain Heart infusion & 18 \\
\hline Proteose peptone & 10 \\
\hline $\mathrm{NaCl}$ & 5 \\
\hline $\mathrm{D}(+)$ Glucose anhydrous & 2 \\
\hline Di Sodium hydrogen phosphate & 2.5 \\
\hline Agar & 15 \\
\hline DDH2O & $1 \mathrm{~L}$ \\
\hline
\end{tabular}

The desired $\mathrm{pH}$ of the media $7.4 \pm 2$

UniversePG I www.universepg.com

\section{Isolation and selection of bacterial isolate}

After incubation bacterial colonies were appeared on the agar surface. The clear discrete and isolated colonies were selected for pure culture. The selected colonies were marked; their cultural characters were studied and recorded. After that the media were streak with all the isolates. The plates were incubated over night at $37^{\circ} \mathrm{C}$. All the isolates show good growth and create a clear zone around the colony. This helps to isolate single colony from the culture.

\section{Stock Culture preparation}

The purified isolates were then transferred to BHIA and TSA medium slant in screw cap vial with the help of sterile loop and incubated at $37^{\circ} \mathrm{C}$ for 48 hours. After incubation, the vials were tightly capped and preserved at $4^{\circ} \mathrm{C}$ as stock culture.

\section{Identification of bacterial isolate}

In order to confirm the identity of the bacterial isolates various cultural, morphological and biochemical studies were performed.

\section{Cultural characteristics}

Culture characteristics of bacterial isolates were studied by inoculating the colonies on BHIA and TSA plates and incubated at $37^{\circ} \mathrm{C}$ for 24 hours. After 24 hours of incubation at $37^{\circ} \mathrm{C}$ colonies on both plates were observed for following characteristics. Diameter of the isolated colonies was recorded in millimeter $(\mathrm{mm})$. Shapes of the isolated colonies were recorded as circular. Colors of the isolated colonies were recorded as light yellow, creamy and brownish. Consistency of the isolated colonies recorded as sticky (Ekhlas et al., 2014).

\section{Morphological characteristics}

Morphological characteristics were determined by Gram staining technique and microscopic examination.

\section{Gram Staining}

The most important differential stain used in bacteriology is the 'Gram Stain', named after Dr. Christian Gram. It divides bacterial cells into two major groups, gram-positive and gram-negative, which makes it an essential tool for classification and differentiation of microorganism. Bacteria were grown on nutrient agar slants at $37^{\circ} \mathrm{C}$ for 24 hours or more according to necessity. A portion of bacterial culture was taken out by a sterile loop and suspended in distilled water. This suspension was made sufficiently diluted. A drop of the 
suspension was taken on the slide and a very thin film was made which was allowed to dry in air. This method was followed for almost all types of staining. The smear was fixed by slightly heating the slide over the gas flame. The slide was allowed to be cool before staining. The Gram stain uses four different reagents: Crystal violet (Hucker's), Gram's Iodine, 95\% Ethyl Alcohol and Safranin. In this procedure, the fixed bacterial smear was treated with crystal violet for 1 minute. This was gently washed in tap water and Gram's iodine was applied for 1 minute. Then gently washed with tap water. After that decolorized the smear 95\% ethyl alcohol. It was applied for 5-10 seconds and gently washed with tap water. Finally, counterstained with safranin for 1 minute and gently washed with tap water. Then dried the smear and it was prepared for microscopic observation.

\section{Microscopic Examination}

All microscopic observations were done by microscopes (Carl Zesis, Model No. 62577, Germany and Olympus, Japan) for 40X magnification oil emulsion were used.

\section{Biochemical Studies of the Selected Isolates \\ Catalase Test}

Catalase is an enzyme produced by many microorganisms that breaks down the hydrogenperoxide into water and oxygen and cause gas bubbles (Uddin et al., 2017). The formation of gas bubbles determines the presence of catalase enzyme and indicates the positive result. Catalase test was performed to isolate in order to see their catalase reactions. For this purpose two methods can be applied. Overnight cultures of isolates were grown on MRS agar at suitable conditions. After $24 \mathrm{~h}$. $3 \%$ hydrogen peroxide solution was dropped onto randomly chosen colony. Also fresh liquid cultures were used for catalase test by dropping 3\% hydrogen peroxide solution onto $1 \mathrm{ml}$ of overnight cultures

\section{Citrate utilization Test}

A loopful of each isolate was streaked onto citrate agar slant and then incubated for a maximum of 96 hours. The citrate test determines the ability of microorganisms to use citrate as the sole of carbon and energy. Simmons citrate agar, a chemically defined medium with sodium citrate as the carbon source. $\mathrm{NH}_{4}{ }^{+}$as nitrogen source and the $\mathrm{pH}$ indicator Bromothymol blue is commonly used for this test when microorganism uti- lizes citrate. They remove the acid from the medium. Which eases the $\mathrm{pH}$ and turns the $\mathrm{pH}$ indicator from green to blue indicates that the microorganisms tested can utilize citrate as its only carbon source.

\section{Carbohydrate fermentation test}

Carbohydrate fermentation test is of great significance of in the identification and classification of bacteria The microorganisms differ in their ability to ferment different carbohydrates. Some of the bacteria produce both acid and carbohydrate fermentation while other produce acid only without gas remaining lots of bacteria cannot tenant carbohydrates. In this study, the fermentation test of the following carbohydrates and sugar alcohols were done (glucose).

For carbohydrate fermentation test, first Phenol redcarbohydrate broth was prepared. In this solution, phenol red indicator was used $8 \mathrm{ml}$ of solution was taken in per tube and sterilized in autoclave at $121^{\circ} \mathrm{C}$ under the $15 \mathrm{lbs}$ for 20 minutes. Then the test organisms were inoculated and incubated at $37^{\circ} \mathrm{C}$ for 24 hours to 48 hours. Positive result was indicated by the change of color from red to yellow.

\section{Antibiotic Susceptibility Test}

Susceptibility testing was based on the Mueller Hinton agar overlay disc diffusion test. Briefly, Pseudomonas and Aeromonas strains were grown overnight in nutrient broth at $37^{\circ} \mathrm{C}$ under anaerobic conditions. Petri dishes containing $15 \mathrm{~mL}$ of Mueller Hinton agar were swabbed with NA enrich Pseudomonas andAeromonas strains and allowed to solidify at room temperature. Antibiotic discs were placed onto the overlaid plates and all plates were incubated at $37^{\circ} \mathrm{C}$ for $24 \mathrm{~h}$ under anaerobic conditions (Rahman et al., 2019). Pseudomonas strains isolated from $M$. armatus is susceptible to penicillin $\mathrm{G}(10 \mu \mathrm{g})$, amoxycillin $(10 \mu \mathrm{g})$, erythromycin $(15 \mu \mathrm{g})$, Tetracyclin $(30 \mu \mathrm{g})$, Kanamycine (30 $\mu \mathrm{g})$, moderately susceptible to Co-trimoxazole $(25 \mu \mathrm{g})$ and Resistance to ceftazidime $(10 \mu \mathrm{g})$ which has been shown in Table 5.

Aeromonas strains isolated from $M$. armatus is susceptible to amoxycillin $(10 \mu \mathrm{g})$, erythromycin $(15 \mu \mathrm{g})$, Tetracyclin $(30 \mu \mathrm{g})$, moderately susceptible to ceftazidime $(10 \mu \mathrm{g})$ and Resistance to Co-trimoxazole (25 $\mu \mathrm{g})$, penicillin $\mathrm{G}(10 \mu \mathrm{g})$, Kanamycine $(30 \mu \mathrm{g})$, which has been shown in Table 5 


\section{RESULTS:}

\section{Culture of bacterial isolates}

Two different bacterial isolates were culture. These bacterial isolates were isolated from different ponds from Jhenaidah region in Bangladesh. Bacterial isolate was culture in the BHIA and TSA Plate.

\section{Characteristics of isolated bacterial strains}

Two different bacterial colonies were inoculated on MRS agar plates and were allowed to incubate at $37^{\circ} \mathrm{C}$ for 24 hours in anaerobic jar. After 24 hours of incubation morphological and cultural characteristics were determined.

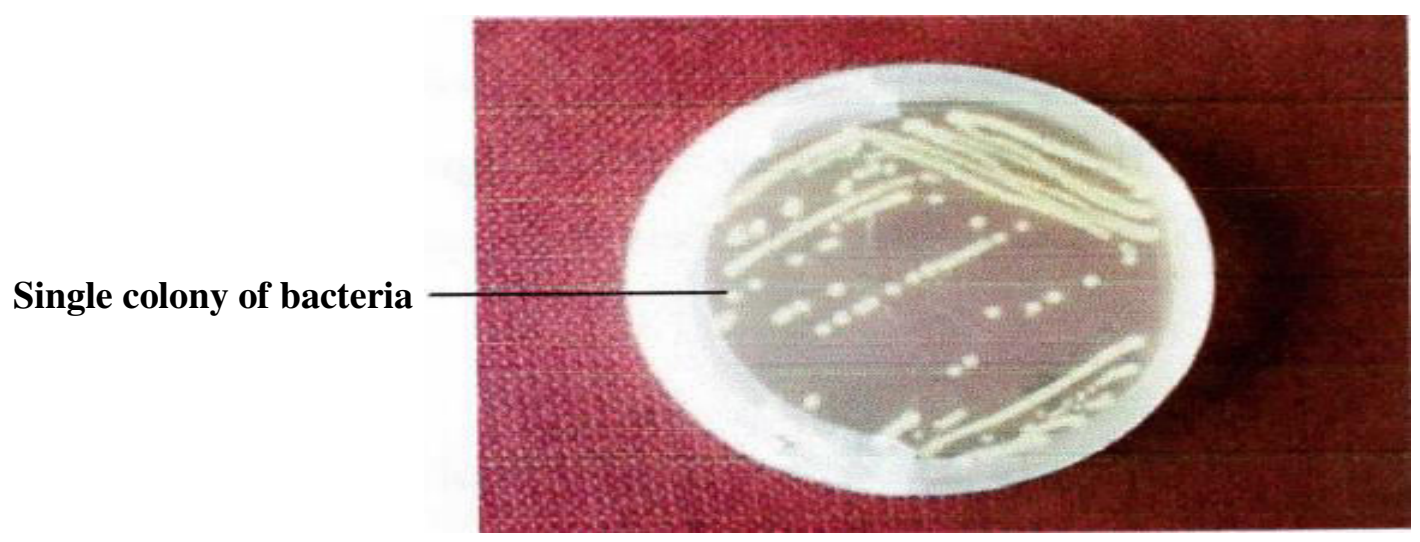

Fig 2: Culture of bacterial isolate in BHIA plate.

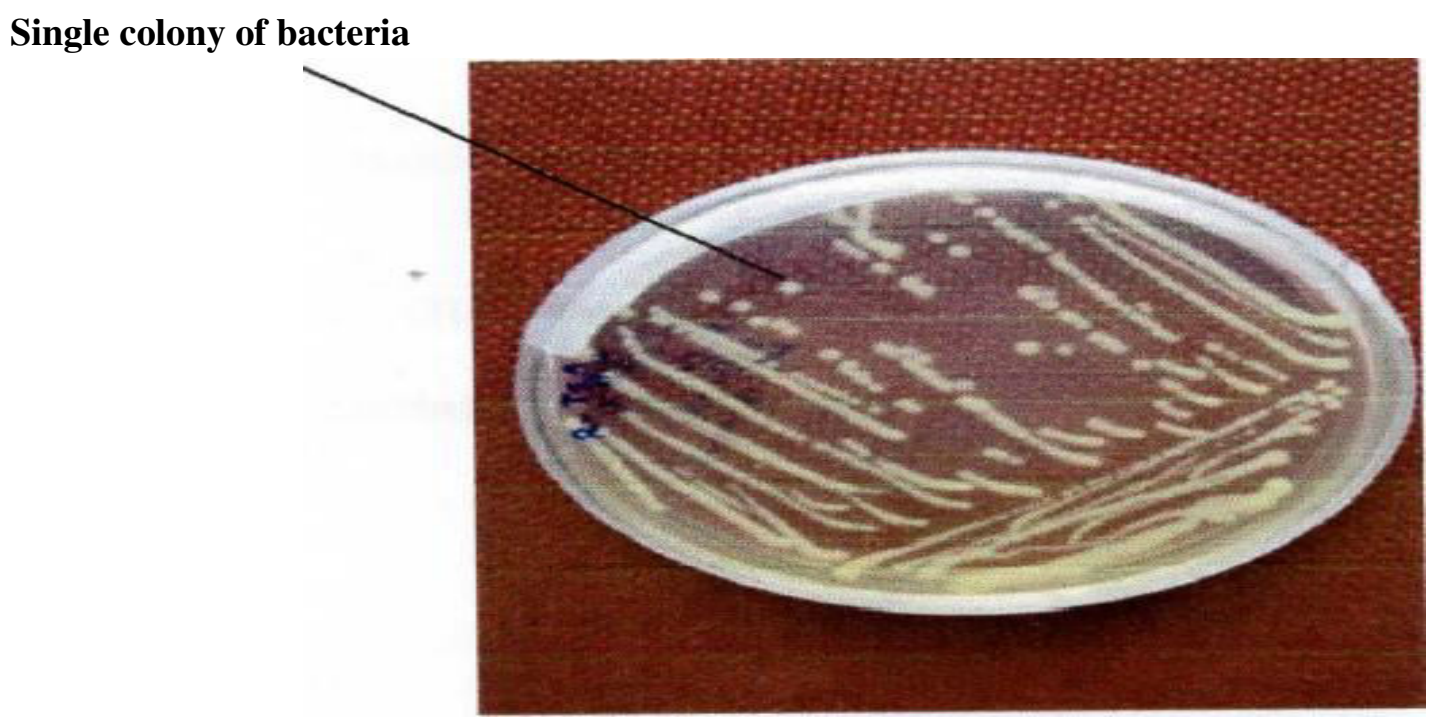

Fig 3: Culture of bacterial isolate in TSA plate.

\section{Morphological and cultural studies}

To identify organisms into taxonomic groups, morphological and cultural studies were carried out. Well isolated colonies were selected and after selection, morphological and cultural characteristics found through
Gram-staining technique and microscopic examination. The following results were found. All isolates were gram-negative and circular shaped bacteria. Their colony color and size was different.

Table 3: Morphological \& cultural characteristics of isolate.

\begin{tabular}{|c|c|c|c|c|c|c|}
\hline \multirow{2}{*}{ Isolate } & \multicolumn{2}{|c|}{ Morphological characteristics } & \multicolumn{4}{c|}{ Cultural characteristics } \\
\cline { 2 - 7 } & Gram staining & Shape & Colony color & Colony size & Colony shape & Consistency \\
\hline MA1 & Grain negative & Rod-shaped & Light yellow & Pin point & Rod- shaped & Sticky \\
\hline MA2 & Gram negative & Rod-shaped & Creamy & Small & Rod- shaped & Sticky \\
\hline
\end{tabular}

MA1=Mystus armatus in BHIA media; MA2= Mystus armatus isolate in TSA media 
Table 4: Biochemical and microscopic tests.

\begin{tabular}{|c|c|c|c|c|}
\hline Isolate & Glucose fermentation & Citrate & Catalase & Gram staining \\
\hline MA1 & + & + & + & - \\
\hline MA2 & + & - & + & - \\
\hline
\end{tabular}

MA1= Mystus armatus in BHIA media; MA2= Mystus armatus in TSA

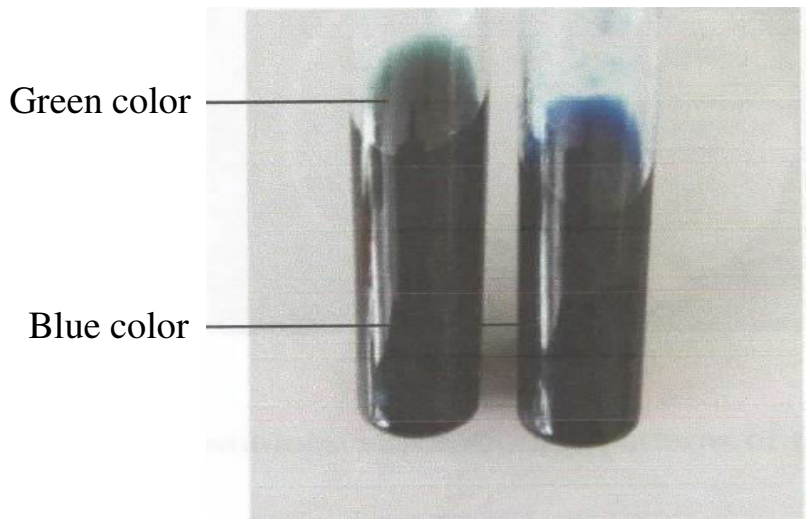

Fig 4: Citrate utilization Test of the isolate MA.

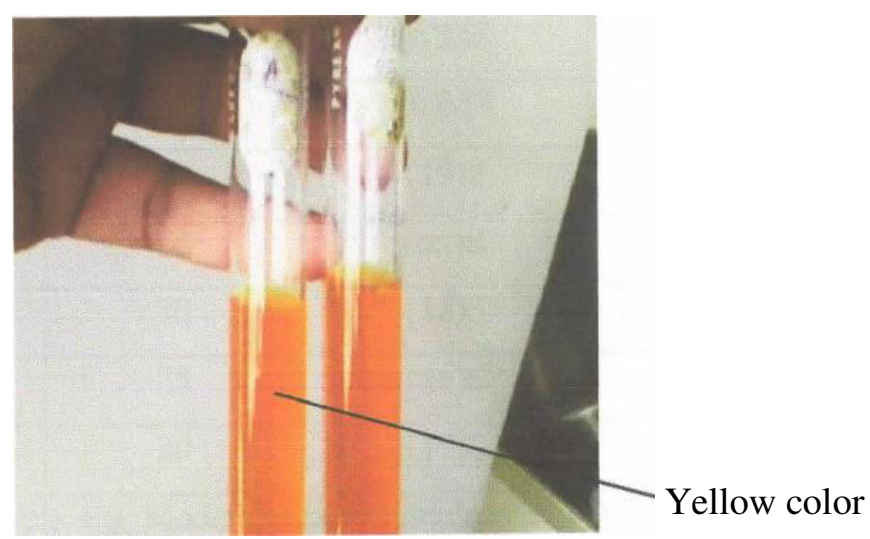

Fig 5: Carbohydrate fermentation test of the isolate MA.

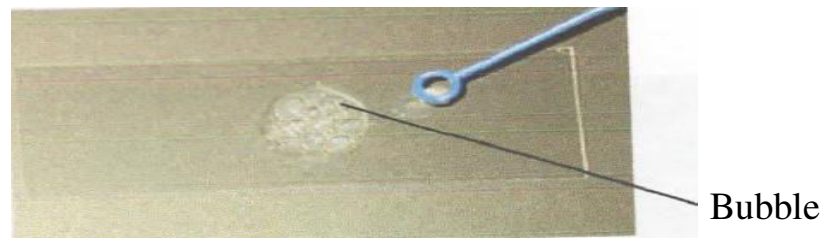

Fig 6: Catalase Test of the isolate MA.

Table 5: Antibiotic susceptibility pattern of the isolate.

\begin{tabular}{|c|c|c|c|}
\hline Name of Antibiotic & Concentration $(\boldsymbol{\mu g} /$ disk) & Isolate-MA2 & Isolate-MA1 \\
\hline Penicillin G & 10 & $(6) \mathrm{MS}$ & $($ nil)R \\
\hline Amoxicillin & 10 & $(6) \mathrm{MS}$ & $(20) \mathrm{S}$ \\
\hline Erythromycin & 15 & $(19) \mathrm{S}$ & $(12) \mathrm{S}$ \\
\hline Ceftazidime & 10 & $(\mathrm{nil}) \mathrm{R}$ & $(23) \mathrm{S}$ \\
\hline Tetracyclin & 30 & $(18) \mathrm{S}$ & $(\mathrm{nil}) \mathrm{R}$ \\
\hline Co-trimoxazole & 25 & $(16) \mathrm{S}$ & $(\mathrm{nil}) \mathrm{R}$ \\
\hline Kanamycine & 30 & $(17) \mathrm{S}$ & \\
\hline
\end{tabular}

N.B.: Susceptible $=$ S, moderately susceptible $=$ MS, Resistance $=$ R

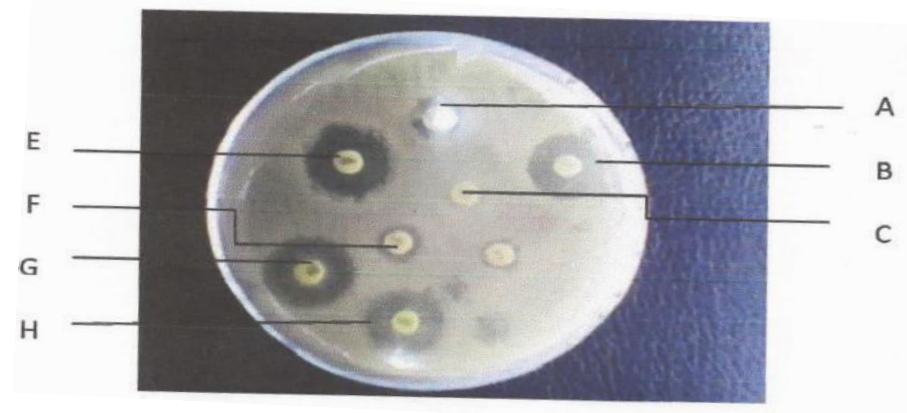

Fig 7: Antibiotic Susceptibility patterns of the isolate MA2.

$\mathrm{G}=$ Tetracycline, $\mathrm{E}=$ Erythromycin, $\mathrm{D}=$ Kanamycin, $\mathrm{B}=$ Co-trimoxazole, $\mathrm{F}=$ Amoxycillin, $\mathrm{C}=$ Ceftazidime, $\mathrm{A}=$ Penicillin $\mathrm{G}$ 


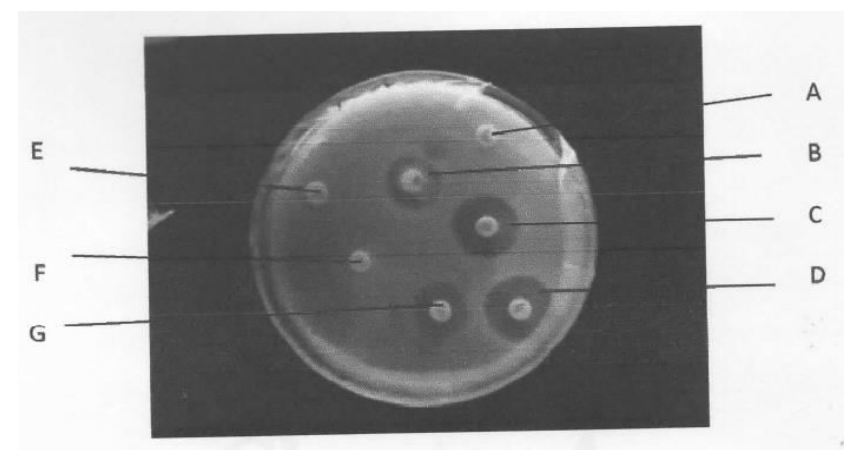

Fig 8: Antibiotic Susceptibility patterns of the isolate MA1.

$\mathrm{G}=$ Tetracycline, $\mathrm{E}=$ Erythromycin, $\mathrm{D}=$ Kanamycin, $\mathrm{B}=$ Co-trimoxazole, $\mathrm{F}=$ Amoxycillin, $\mathrm{C}=\mathrm{Ceftazidime}$, $\mathrm{A}=$ Penicillin $\mathrm{G}$

\section{DISCUSSION:}

Fish are the main source of protein in Bangladesh. It is one of the most important groups of vertebrates which give benefits to human beings in several ways. Many of the affect fishes are considered opportunists, attacking the fishes when they are stressed or immune compromised because of unfavorable environmental conditions, or secondary to bacterial or viral infections, or when they have lost their mucus protection because of trauma or excessive handling. Most of the multiple case reports or single and causing systemic disease with high mortality rates in fishes. The common and important pathogens in aquaculture, such as Aeromonas hydrophila, Aeromonas veronii, Aeromonas jandaei, Streptococcus agalactiae, Streptococcus iniae, Streptococcus dysgalactiae, Edwardsiella tarda, Pseudomonas sp., Lactococcus garvieae, Citrobacter freundii, Plesiomonas shigelloides, and Enterococcus sp. which causes hemorrhagic septicemia, characterized by small superficial lesions, focal hemorrhages, ulcers, abscesses, and abdominal distension.Internally, there can be ascitic fluid accumulation, anemia, and lesions in the liver and kidneys (Quiniou et al., 1998). Some common viruses named Herpesvirus cyprini (Cyprinid herpesvirus 1), Iridovirus, Rhabdovirus causes disease in culture fish Viral Hemorrhagic septicemia, Lymphocystis Disease, Herpesvirus salmonis (Muller, 2016).

Pseudomonas fluorescens, $P$. angulliseptica, $P$. aeruginosa and $P$. putida are and Aeromonas hydrophila, $A$. veronii, $A$. jandaei the main strains identified in various species of fish as causative agents of Pseudomonas and Aeromonas septicaemia (Akayl et al., 2004; Altinok et al., 2006; Sakar et al., 2008; El-Nagar et al., 2010).

UniversePG I www.universepg.com
Pseudomonas and Aeromonas has been reported to cause disease in a number of fish species, including goldfish, Carassius auratus. Pseudomonas and Aeromonas have been isolated from Gilthead sea bream, Sparus auratas, European seabass, Dicentrachus labrax and challenges have caused mortalities in carp and local variety fishes, Cyprinus carpio and loach, Misgurnus anguillicaudatus, M. armatus. However, other species of the genus may also induce serious infection like $P$. putida \& and Aeromonas hydrophila infection in rainbow trout Oncorhynchus mykis (Altinok et al., 2006). The putative isolates were rod-shaped. Gram negative results are shown in Fig 2 and Fig 3. After some biochemical tests the isolates was nominated Pseudomonas genus and Aromonas genus. The respective isolates were catalase positive, as well as one has ability to utilize citrate as energy sources and another has no ability to utilize citrate; results are shown in Fig 4 and Fig 6. Pseudomonas and Aeromonas species is Gram-negative, rod-shaped, none spore forming bacteria, distributed widely in nature and found in soil and in water (Tripathy et al., 2007). Pseudomonas was fully enabled to ferments glucose and Aeromonas was enabled to ferment glucose as carbon sources, results are shown in Fig 5.

Accordingly bio-chemical tests were conducted as per Bergey's Manual of determinative bacteriology as well as from the published data and experimental data found by work we can declare that the isolates were identified from the sample are belong to pseudomonas and Aeromonas genus. For further characteristics we should follow molecular technique such as 16s rDNA technology. Pseudomonas strains isolated from $M$. armatus 
is susceptible to penicillin $\mathrm{G}(10 \mu \mathrm{g})$, amoxycillin (10 $\mu \mathrm{g})$, erythromycin $(15 \mu \mathrm{g})$, Tetracycline $(30 \mu \mathrm{g})$, Kanamycine $(30 \mu \mathrm{g})$, moderately susceptible to Co-trimoxazole $(25 \mu \mathrm{g})$ and Resistance to ceftazidime $(10 \mu \mathrm{g})$ which has been shown in Table 5. Aeromonas strains isolated from $M$. armatus is susceptible to amoxycillin $(10 \mu \mathrm{g})$, erythromycin $(15 \mu \mathrm{g})$, Tetracycline $(30 \mu \mathrm{g})$, moderately susceptible to ceftazidime $(10 \mu \mathrm{g})$ and Resistance to Co-trimoxazole $(25 \mu \mathrm{g})$ penicillin $\mathrm{G}(10 \mu \mathrm{g})$, Kanamycine $(30 \mu \mathrm{g})$, which has been shown in Table 5. Knowledge of this study will be helpful to fish pathologist, fish culturists and researchers to detect ulcer type disease and to take necessary measures against the bacterial pathogen.

\section{CONCLUSION:}

The infected fish ( $M$. armatus) act as a reservoir of highly pathogenic bacteria such as Pseudomonas spp and Aeromonas spp. The present study will give some basic knowledge about the pathogenecity of bacteria and virulence mechanisms of potential bacteria fish pathogen, which will help to control the incidents of infection in aquaculture facilities. The knowledge of the study will be useful to fish farmers and culturist in the maintenance of fish health and thus will support for improvement of fish productions which ultimately reflects the economy of the country. Antibiotic susceptibility studies are necessary to establish the appropriate antibiotic measure against the high virulent, medium virulent and low virulent isolates to recover from pathogenic bacterial disease.

\section{ACKNOWLEDGEMENT:}

We acknowledge host laboratory and supervisor $f$ the research study for the cooperation and also for his technical support.

\section{CONFLICTS OF INTEREST:}

The authors have declared there is no competing interests exist.

\section{REFERENCES:}

1) Abdullah-Bin-Farid B.M.S., Mondal, S., Satu, K.A., Adhikary, R.K. Saha, D. (2013). Management and socio-economic conditions of fishermen of the Baluhar Baor, Jhenaidah, Bangladesh. Journal of Fisheries, 1(1): 30-36. https://doi.org/10.5281/zenodo.4459278
2) Abedin MZ, Aktar MB, Sifat Uz Zaman M, Hasan R, Jarin L, Karim MR, Rahman MS, Islam R, Uddin M. E. (2020). Occurrence and antimicrobial susceptibility profiling of bacteria isolated from cultured Pangas Catfish (Pangasius pangasius) and Climbing Perch (Anabas testudineus) Fishes. J Marine Biol Aquacult. 6(1): 712. https://doi.org/10.15436/2381-0750.20.2743

3) Abisoyc, B.F., Ojo, S. K. S., Adeyemi, R. S. and Olaiuvigbe, O. O. (2011). Racteriological assessment of some commonly sold fishes in Lagos metropolis market Nigeria. Prime J. of Microbiology Research. 1(2): 23-26. https://www.academia.edu/10012148

4) Adibe, NC., Eze, El. (2005). General Laboratory Techniques for Tertiary Institutions, Mike Social Agbede SA, Adeyemo OK, Adedeji 0, and Junaid AU Ultrastructural study of the phagocytic activities of splenic macrophages in tilapia (Oreochromis niloticus). Aft. Biotechno., 15(22): 23502353.

5) Ahmed, G. U., Dhar, M., Khan MNA Choi, J. (2007). Investigation of diseases of Thai koi, Anabas testudineus (Bloch) from farming conditions in winter. Korean Journal of Life Science. 17(10): 1309-1314. https://doi.org/10.5352/JLS.2007.17.10.1309

6) Akayl, T. Timur G, (2004). Septicemia caused by pseudomonas in young ranbow trout. Vet. Fakultesi Dergisi, Istanbul, Turkey. 30(1): 121131.

7) Alicia E, Toranzo T, Magarinos B, Romalde SL. (2004). Aquaculture. 246: 37-61.

8) Altinok I, Balta F, Capkin E, Kayis S. (2007). Disease of rainbow trout caused by Pseudomonas luteola. Aquaculture; 273(393): 397.

9) Altinok, IS. Kayis, Capkin E. (2006). Pseudomonas putida infection in rainbow trout. Aquaculture. 261: 850-855. https://doi.org/10.1016/j.aquaculture.2006.09.009

10) Austin B, Austin DA. (1999). Bacterial fish pathogens: disease to Tarmed and wild fish, $3^{\text {rd }}$ ed. Praxis Publishing Ltd, Chichester. Pp. 29-32.

11) Austin, B. D.A. (2007). Austin, Bacterial Fish Pathogens. Diseases of Farmed and Wild Fish. Springer-Praxis Publishing Ltd., United Kingdom. 
12) Balachandran, K. K. (2001). Post-harvest Technology of Fish and Fish Products, Days Publishing House, Delhi, 2(18).

13) Biswas, M. M. R., Islam, M. F., Rahman, M.M., Kawsar, M.A. Barman, S. K. (2009). Fisheries Management scenarios of two boars in the district of Chuadanga, Bangladesh. J. of Innovation and Development Strategy, 13(5): 11-15. http://ggfjournals.com/assets/uploads/11-15.pdf

14) Chao, K. K., Chao, C. C. Chao, W. L. (2003). Suitability of the traditional microbial indicators and their enumerating methods in the assessment of fecal pollution of subtropical freshwater environments. Journal of Microbiology Immunological Infection, 36: 288-293.

15) Chowdhury, M. B. R., Muniruzzaman. M., Zahura, U'A., Habib, K. Z. A. Khatun, M. D. (2003). Ulcer type of disease in the fishes of small-scale farmer's pond in Bangladesh. Pakistan Journal of Biological Science, 6: 544-550. https://scialert.net/fulltext/?doi=pjbs.2003.544.550

16) DoF, (2011). Yearly report, Dept. of Fisheries, Ministry of Fish and Livestock, December, 2011. 09.

17) DoF, (2012). Fish, Livestock News (monthly), Ministry of Fish and Livestock, Registration No. 965, 11, January 2012.

18) Ekhlas Uddin Md., Pulak Maitra, Hossain Md. Faruquee, Firoz Alam Md., (2014). Isolation and characterization of proteases enzyme from locally isolated Bacillus sp., American Journal of Life Sciences. 2(6): 338-344. https://doi.org/10.11648/j.ajls.20140206.12

19) El-Nagar, R.M.A. (2010). Bacteriological studies on Pseudomonas microorganisms in cultured. M.V.Sc. thesis, Fac. Vet. Med., Zag University.

20) Eze, El., Echezona, B.C. Uzodinma, E.C. (2009). Isolation and identification of pathogenic bacteria associated with frozen mackerel fish (Scomber scombrus) in a humid topical environment. African J, of Agricultural Research, 6(7): 1918-1922. https://doi.org/10.5897/AJAR.9000449

21) Eze, El., Echezona, B.C. Uzodinma, E.C. (2005). Isolation and identification of pathogenic bacteria associated with frozen mackerel fish (Scomber scombrus) in a humid tropical environment.
African Journal of Agricultural Research, 6(7): 1918-1922.

22) Faruk, M.A.R., Alam,M.J., Sarker, M.M.R.Kabir, M.B. (2004). Status of fish disease and health management practices in rural freshwater aquaculture of Bangladesh. Pakistan Journal of Biological Science.7, 2092-2098.

23) Faruk MAR, Alam MJ, Alam, Sarker, MMR, Kabir, MB. (2004). Pakistan J. Biol. Sci, 7(12): 2092-2098.

http://www.docsdrive.com/pdfs/ansinet/pjbs/2004/2 092-2098.pdf

24) Foysal MJ. (2010). Tail and fin rot disease of Indian major carp and climbing perch in Bangladesh. J. of Biological Sciences, 10: 800-804.

25) Grimes DJ, Stemmler S, Hada H, May EB, Maneval D, Hetrick, FM. (2007). Vibrio species associated with mortality of sharks held in captivity. Microbial Ecology. 10(3), 271-282. https://pubmed.ncbi.nlm.nih.gov/24221148/

26) Hossain MA. (2008). Isolation of pathogenic bacteria from the skin ulcerous symptomatic gourami (Colisa lalia) through 16SrRNA analysis. Univ. J. Zool. Rajshahi Univ. pp. 21-24.

27) Hossain, M. (2008). Isolation of pathogenic bacteria from the skin. Ulcerous Symptomatic Gourami through 16s rRNA analysis. Inter. J. Univ. Zool. Rajashahi Univ., 27: 21-24.

28) Khartoum Central Market, (2004). Sudan J. Vet. Sci. Animal Husbandry, 43(1-2): 32-37. https://doi.org/10.15761/AHDVS.1000142

29) Khoi, (2008). "Farming system practices of seafood production in Vietnam: the case study of Pangasius small-scale farming in the Mekong River Delta," ASEAN business Case studies, Center for ASEAN studies. 27.

30) Mhango, M., Mpuchane, S. F. and Gashe, B. A. (2010). Incidence of indicator organisms, opportunistic and pathogenic bacteria in fish. African $J$. of Food, Agriculture, Nutrition and Development. 10(10): 4202-4218. https://www.ajol.info/index.php/ajfand/article/view/ $\underline{62898}$

31) Noga, E.J. (1996). Fish disease diagnosis and Irealmeni. Mosby-Year Book, Inc., St Louis Missouri. 63146-367. 
32) Rahman MM and Chowdhury MBR. (2005). Isolation of bacterial pathogen causing an ulcer disease in farmed carp fishes of Mymensingh. Bangladesh Journal of Fisheries. 19: 103-110.

33) Rahman MA, Ahmad T, Mahmud S, Uddin ME, and Ahmed R. (2019). Isolation, identification and antibiotic sensitivity pattern of Salmonella spp. from locally isolated egg samples, Am. J. Pure Appl. Sci., 1(1): 1-11. https://doi.org/10.34104/ajpab.019.019111

34) Sakar, S.F.M. and M.M.A. Azza. (2008). Contribution on Pseudomonas septicemia caused by P. anguilltheptica in cultured Oreochromis 218: 1; 1-20. Niloticus. Fish Diseases Dept., Central lab for Aquaculture Research, Abbassa, and Agriculture Research Center, Egypt. 11(77): 1197.

35) Somsiri T, Soontornvit S. (2002). Bacterial diseases of cultured tiger frog (Rana tigrina). Diseases in Asian Aquaculture IV, Fish Health Section, Asian Fisheries Society, Manila. 15-17.

36) Sujatha, K., Sangeeta, S. and Gopalakrishnan, M. D. (2013). Isolation of human pathogenic bacteria in two edible fishes, Priacanthus hamrur and Megalaspis cordyla at Royapuram waters of Chennai, India. Indian Journal of Science and Technology. 4(5): 539-541. https://doi.org/10.17485/ijst/2011/v4i5/30057
37) Uddin MM and Ahmed AH. (2004). J. Appl. Aquacul. 2(1): 53-61.

38) Uddin M. E., Ahmad T., and Ahammed T. (2017). Thermotolerant extracellular proteases produced by Bacillus subtilis isolated from local soil that representing industrial applications. $J$. of Pure and Applied Microbiol. 11(2): 733-741. https://doi.org/10.22207/JPAM.11.2.12

39) Verschuere L, Rombaut G, Sorgeloos P, Verstraete W. (2000). Probiotic bacteria as biological control agents in aquaculture. Microbiol. Mol. Biol. Rev, 64: 655-671.

https://www.ncbi.nlm.nih.gov/pmc/articles/PMC99 $\underline{008 /}$

40) Verschuere L, Rombaut G, Sorgeloos P, Verstraete W. (2000). Probiotic bacteria as biological control agents in aquaculture. Microbiol $\mathrm{Mol}$ Biol. 64: 655-671.

https://www.ncbi.nlm.nih.gov/pmc/articles/PMC99 $\underline{008 /}$

41) Yagoub, S.O. (2009). Isolation of Enterobacteria and Pseudomonas species from raw fish sold in fish market in Khartoum State. J. of Bacteriological Research. 1(7): 85-88.

http://www.academicjournals.org/app/webroot/artic le/article1379947262_Yagoub.pdf

Citation: Sarker RK, Alam MK, Hossain MA, Badiruzzaman M, Hamid A, Rabbni MAA, and Islam MR. (2021). Isolation and identification of pathogenic bacteria from Baime fish (Mystus armatus) and evaluation of antibiotic susceptibility. Eur. J. Med. Health Sci., 3(6), 136-146.

https://doi.org/10.34104/ejmhs.021.01360146 @) (i) 